\title{
The Impact of Strategic Leadership on Competitive Advantage: The Mediating Role of Ambidexterity and Information System: Evidence from Islamic Banks in Jordan
}

\author{
Amena Sibghatullah ${ }^{1, *}$, Muhammad Raza ${ }^{2}$ \\ ${ }^{1}$ College of Management Sciences PAF-KIET University, Pakistan \\ ${ }^{2}$ Universiti Utara Malaysia, Malaysia \\ 1 amenasibghat@gmail.com* \\ * corresponding author
}

(Received September 16, 2020, Revised September 19, 2020 Accepted September 24, 2020, Available online September 30, 2020)

\begin{abstract}
The purpose linked with the existing study is to examine the impact of strategic leadership on the competitive advantage of the Islamic banks in Jordan. The mediating analysis of organizational ambidexterity and information system among the links of strategic leadership on the competitive advantage of the Islamic banks in Jordan also included in the aim of the ongoing study. This study has executed the quantitative techniques of data collection through which data has been gathered from the employees of the Islamic banks by using questionnaires. The analysis part of the existing study has been accomplished by using the AMOS. The results indicated that the positive nexus has been found among the links of strategic leadership and competitive advantage while the findings also exposed that the ambidexterity positive mediates among the links of strategic leadership and competitive advantage of the Islamic banks in Jordan. These findings provided the guidelines to the regulators while formulating regulation for competitive advantage along with leadership and also helpful for the future studies who aim to investigate this area in the future.
\end{abstract}

Keywords: Strategic Leadership; Commutative Advantage; Islamic Banks in Jordan; Ambidexterity;

\section{Introduction}

The concept of leadership is referred to the potential of managers where the expression of strategic vision is countered. Various means of strategic leadership are concluded from the implication of strategic capabilities. The ultimate responsibility lies on managers which induce various dimensions of strategic capabilities toward the markets for retaining a sustainable and competitive environment. The potential of managers is dominant means for the organizations through its visionary analysis which helps to attain various objectives and enhancing motivations toward acquiring vision. The eminence of strategic visioning helps the strategic leadership to utilize the strategic view towards the employees of management. With the help of strategic learning, the ways of getting smarter could be enhanced for competitions in attaining competitive advantage [21][41]. It is the managers potential to employ strategies that influence the members of organizations as well as for the execution of change in an organization. Usually, the leaders having strategic capabilities creates the structure of organizations, resource allocation and expresses strategic visions. Usually, the performance of employees is based on the rewards that are given while focusing their performance on competitive markets. Many organizations are known in the competitive environment due to the implication of strategies by strategic leaders which are well known in competitive markets. There is a significant role of entrepreneurial orientation and leadership on the retention of employees while the role of competitive advantage is also dominant [12][44].

The strategic leaders usually work in difficult environments which are influenced by certain occasions. Strategic leadership is usually bound to employ strategic productivity through its exceptional skills which are usually required in various aspects. Various occasions prevail in the organization that relates to external and internal environment influences directly or indirectly on the working conditions. The ultimate planning could be enhanced by the strategic leaders through various techniques which then becomes a measure for attaining 
advantage over other companies. The planning and perception are also dominant terms which are the basic technique which leaders employ but the effective strategies by leaderships help in enhancing the realization of goals. Seeking the achievements in organizations would always require behavior of competence in the working environment. Various analyzation prevails for the competencies through the business environment, management and creation of knowledge [25][32]. For completion of various tasks, it is important to have the capability of competence which insert effective role in the completion as well as efficiency. Various scales are developed by the organizations to induct the capabilities of competing in a competitive environment. The variation in sets of skills are employed by workers as well as leadership, but the effective role of leadership dominates the accomplishment and motivation of employees. Every business requires the process of strategic planning which could be executed at the initial stage or the level of a competitive environment. Systems of information in business could be established through the strategic planning for dominant integrated systems in companies [19][40].

Strategic leadership insert dominant role over the competitive advantage through the implication of strategic planning. Although, strategic planning is the dominant term which prevails among the behavior of strategic leaders the effectiveness must dominate over the strategic leadership for employment. Many businesses are directed toward the competitive environment after the implication of strategic planning. While the strategic leaders are countered as responsible for the induction of effective planning which could assert significant results from the competitive markets. Strategic leaders aim to employ a feasible environment for employees for better forecasting of attaining various aims and objectives. There are segments of businesses where the element of rethinking is dominant through the strategic insights and conceptual building of models in business markets [10][14]. Companies improve the skills of thinking through various implications of strategic while the prevalence of leaderships could be dominant for the effectiveness of organizational structure over the markets. Many companies strive in the global environment to attain a competitive advantage over other companies.

Various stages prevail in the global markets for attaining and retaining the competitive advantage while the strategic capabilities also dominate achievement. Companies employ various strategies to enable a sustainable environment for a competitive advantage. Different strategic issues prevail in organizational environments which are dominant in the achievement of better competitive advantage. Exercising of strategic leadership could influence the enterprises that have sustained performance in social forms [3][26]. For the attainment of competitive advantage, the companies must develop various schemes to understand the segments and markets while emphasizing competitors. It is usually eminent for the companies to understand the structure of various companies that are dominant in achieving competitive advantage. Companies usually focus on the consumers what they need; therefore, effective strategic planning is required to attain the objectives. Studies mentioned the differences in strategic implications which are dominant for the competitive advantage in global markets. Competitive advantage is obtained through the induction of various strategies that have an imminent impact on the growth of organizations. The form of the ability which renders the equal use of both hands while referring humans where the capabilities are highlighted. The qualities prevail in any man that contributes best toward the organization through its dominant capabilities and techniques. The abilities of individuals as well as ambidexterity help companies to pursue activities enumerated as an influence on the performance of firms [15][46]. The comparison of human that is capable of using both hands with the other humans is indistinct due to vast capabilities. Leadership qualities are ascertained through various tests; the prevalence may arise from markets of its skills that contribute much to the organization. Most humans have capabilities of contributing through a variety of techniques while the other has regular techniques that are having no name of innovation in the organization.

The baking sector of any country is considered as the backbone of the economy. As this sector is attached to several other sectors. The importance of this sector cannot be ignored at any stage during economic 
development. This investigation is conducted in the banking sector of Jordan. In the banking system of Jordan, the capital adequacy ratio stands at $18 \%$ in between 2007-2016. There was a decline from 17.8 to 16.9 during 2017-2018. This noticeable decrease resulted in the introduction of IFRS. The ratio of non-performing loans to total loans was decreasing from 2010-2017 and stands at 2.4\% at the end of 2017. In the case of liquidity, the banking system of Jordan enjoys safe liquidity. The total high liquidated assets counted at $44.9 \%$ in 2018 and $45.8 \%$ in 2018 . The return on assets (ROA) increase from $9.1 \%$ to $9.6 \%$ from 2017 to 2018 . There was a decline reported in the rate of credit granted by the banks in a comparison between 2017 and 2018. Direct credit facility-DCT increase by 5.3\% during the year of 2018 and reached to JD 25.7 billion. The same was $8 \%$ in 2017 . The decline in growth is resulting in a decline in economic activities in Jordan. In the banking sector, the testing adequacy ratio was $16.5 \%, 15.7 \%$ and $14.8 \%$ in 2019,2020 and 2021 respectively. The financial stability index maintains its level in the year of 2018. The same was 0.46 in the year of 2017. There is an improvement reported in the banking system. The ratio of total expenses to total income in the banking system was reported $56.2 \%$ in the year 2017 and $55.5 \%$ in the year of 2018 . There is a risk associated with the household sector. In the year 2018, this risk decreased as a comparison with previous years. Its amount was $40 \%$ of the total expenses in the year of 2018. In the same way, there are mix indicators from the Jordan banking system.

\section{Literature Review}

\subsection{Strategic leadership significantly influences the competitive advantage of the Islamic banks in Jordan.}

The ability of competence is hidden in managers who are responsible to insert it efficiently for grasping the company's overall strategies and employ individual efficacy for the attainment of advantage. The roles of creativity have much eminence toward the organizations in the context of developing the competence of international business [13]. Managers usually make sure about the goals and directions which are developed by the manager's behavioral competency over the employees which strive for the same objective. Strategic leaderships is known as encouraging element for the workers which follows the ideas developed by their capabilities. The process of strategic planning is dominant due to consistent adaptations for the enhancement of organizational performance [20]. Usually, the strategic planning is directed by the strategic leadership which develops a road map of business directions where the existence and goings are evaluated. Various missions, values and visions are also the evaluated structure of strategic planning executed by the strategic leaders; therefore, the existence of strategic planning is significant for businesses. Various strategies are employed by strategic leaders which comprise the induction of assessment through creating ideas, views, and analyzing. Business process help employees to enhance their brains through the stimulation of learning activities creating strategic thinking [16]. Studies have mentioned strategic thinking important tolls for effective working as well as valuable achievements in a competitive world. Many elements prevail in the organization where the exploration and exploitation are stimulating things differently; therefore, ambidextrous leadership help to balance the situation. Many companies strive in a competitive market to attain a competitive advantage; therefore, the significance of ambidextrous leadership usually helps in attaining vast advantages. Strategic capabilities are analyzed by emphasizing the ambidexterity of organizations through the knowledge management presence [1]. For efficient innovation through team stimulation, leadership having ambidextrous qualities inserts dominant measures to balance the organizational structure. The navigation of tensions among products and innovations are significantly distributed by ambidextrous leadership. Various companies enhance their organizational structure and capabilities by inducing the strategic implications of competitive advantage sustainability. Companies establish various strategic implications that help in the attainment of goals and objectives while the dominance of support and flexible measures could assert competitiveness. Competitive advantage is attained through various process of business while, strategic capital humanity has dominant role [28]. Strategic leaderships inserts various measures in the organizations toward the competitive advantage; therefore, the links between competitive advantage and strategic leadership has a dominant role. 
The development of attitudes by strategic leaders toward the effectiveness of work induces many variations in the achievement of tasks. It could be asserted as positive and negative forms of achievement; therefore, the eminence of strategic competence have a significant role in the competitive advantage. Studies analyzed various incidents that are critically related to crisis management; therefore, competencies have a dominant role through attributes globally [11][23]. Wide studies have enumerated the element of strategic competence as an important factor which contributes significant results toward the competitive advantage. Using effective skills, knowledge and attitude, many strategic leaders with the capability of competence could functions dominantly for the competitive advantage in the external environment. The overall dominance of competency prevails among the managers who retain the capability of competence and enhance operational competence through various strategies. Levels of achievements are attained through the employment of competence structure where managers could insert their skills and competence in the competitive environment. Studies elaborated the interactions that are complex and related to the social entrepreneurs in various missions of market development [31]. It is pertinent to mention about the capabilities and competence of organizations which strive in the market for various advantage, but the cores of strength and weakness also dominate.

Various businesses prevail in the global environment which requires effective planning but before it, the prevalence of strategic leaderships must be dominated. Strategic management has a dominant role in the structure of companies where the actions and goals are planned by strategic leaders through the employment of dominant techniques. Many things could be omitted of overlooked while striving toward the effectiveness of plans; therefore, written instructions could help to retain the road maps. Planning always moves toward the decision-making process; therefore, in the absence of strategies, the strategic planning inserts a vital role for decisions of businesses [22][36]. For succeeding the competitive environment, the role of strategic planning is important whilst the role of strategic leader usually inducts the process of planning. Strategic plans significantly help companies to retain various objectives that are developed at the initial stages of business. The strategic plans that are well written could be enumerated as a significant response to the success and growth of the business. Numerous interactions have been enumerated in studies that have dominant effects over the innovations and leadership while the competitive intensity also influenced by the behaviors of performances [45]. Various balancing environments prevail between the consumer and organizations; therefore, effective strategies by leadership assists in retaining the relation among both.

Strategic thinking is an important element in defining the process of business that could assert dominant results in competitive markets. Companies having strategic leaders could assert better strategic thinking over the markets which helps in competitive advantage. The greater use of incentives and rewards are dominantly made by strategic leaders to the employees which enhance their capabilities for doing splendid work. The dominance of strategic thinking helps in improving the working practices as well as the performance of organizations whereas the perspectives of systems are different [4][38]. Decision making is an important element in business which insert dominant influence over the global markets for better profits as well as retaining the sustainable environments. Studies discussed strategic thinking as an important tool that is implicated by strategic leaders for the competitive advantage in open markets. Where the prevalence of strategic thinking is dominant, the results interpreted in studies have a significant contribution to enhancing the capabilities of organizations. Collectiveness of engagements dominates the business while it also enumerates the service performance, competitive intensity and shared vision [17]. Relations between customers and companies have a strong influence over the other companies due to the opportunities of competitive advantage. 


\subsection{Ambidexterity significantly influences the competitive advantage of the Islamic banks in Jordan.}

Many managers usually refrain from doing the activities of the battle that exists in the atmosphere of various organizations where the dominance of ambidextrous insert vital role among the strategic leadership and competitive advantage. For the opportunities in an organization, the relationship between organizational ambidexterity and managers have a dominant effect [30][37]. Eminent role of ambidextrously has been enumerated in a variety of studies that induces a dominant role among the competitive advantage and leadership. Mostly, small businesses have been reviewed as efficient strategic views where the structure of competence has inserted much for the competitive advantage. Usually, in the industrial action of strategic competency is required to be adapted with the dominance of skills and knowledge that could enhance the achievements. Dominant interactions have been enumerated in wide studies mentioning the significance of business competencies and performance of exports [9]. Numerous hurdles are eliminated by the competence of managers which also help companies in rapid growth. Many companies exist on the environment of developing strategic competence which could render better results for the evaluation of significant competitiveness. Induction of various purposed ideas of service and delivery also poses an imminent impact on the competitive advantage. Studies clarified the relation among competitiveness, marketing and strategic views for the competitive advantage [35]. The significant distribution of capabilities into the global environment could assert a better competitive advantage.

\subsection{Ambidexterity significantly mediates among the relationship between strategic leadership and competitive advantage.}

It is obvious that many objectives are attained through proper planning and strategic thinking; therefore, the existence of ambidextrous could be dominant among the effectiveness of factors. Various process and mechanisms have been introduced through top management that strengthens the organizational ambidexterity [24][43]. The element of ambidextrous prevails in leadership or behaviors of humans which insert effective role in the achievement of goals. Therefore, effective strategic planning help employees to be structured more effectively toward the numerous challenges and opportunities that exist in competitive environments. For the sake of turnover intentions, the element of strategic planning is countered as combat strategy [5]. Strategic planning endorses various implications where the assessments are performed based on objectives and plans. Usually, the plans are dominated verbally in various organizational environments while the written plans have more effectiveness than verbal planning's. The element of strategic fit is nominated in studies as a dynamic capability that helps to attain competitive advantage [18]. Services and qualities are maintained in the market through various implications of strategic reasoning which may include branding, quality, service, and pricing.

The dominance of ambidextrous tends to be dominant in the abilities of human behavior toward the organizations which have effectiveness to flexible environments in strategic formation. It inserts eminent role in the reduction and increase of variances in strategic behaviors among organizational planning and thinking. The empowerment of ambidexterity and leadership has inserted a vital role for organizational improvement [2][42]. Most of the leaders having capabilities of ambidextrous support employees and followers to adapt the capabilities of ambidextrous. Leadership has a dominant role in the enhancement of the company's growth; therefore, through strategic thinking, many objectives could be much easier than predicted. While considering the role of spiritual intelligence, strategic thinking inserts a dominant role in self-efficacy [27]. Future trends to be unpredicted; therefore, induction of strategic thinking helps companies to attain the levels of decision making which are helpful in competitive advantages. Adaptation of leadership and consciousness is mentioned in studies as a dominant element for the competitive advantage [7]. The competitive advantage has 
significance toward the growth and sustainability of companies which strive for variation of advantages against similar products.

\section{Method}

The study aims to investigate the impact of strategic leadership on the competitive advantage of the Islamic banks in Jordan along with the mediating analysis of organizational ambidexterity among the links of strategic leadership on the competitive advantage of the Islamic banks in Jordan. This study has executed the quantitative techniques of data collection through which data has been gathered from the employees of the Islamic banks by using questionnaires. These questionnaires have been distributed among the respondents by using simple random sampling and forwarded about 450 questionnaires by personal visit. However, only 320 questionnaires have been received after one month and used for the analysis that represents about 71.11 percent response rate. The analysis part of the existing study has been accomplished by using the AMOS due to the purpose of the study is hypotheses testing. The variables that have been used in the ongoing research has only one predictor named as strategic leadership (STLS) that has nineteen items [34]. In addition, competitive advantage (CA) has been used as the predictive variables that have twelve items [33]. Finally, the ambidexterity (AMD) has been used as the mediating variables that have eleven items [29]. These items and shown in below Table 1, Table 2 and Table 3 while figure 1 shows the theoretical framework.

Table. 1. Scale of Strategic Leadership

\begin{tabular}{|c|c|}
\hline Items & Statements \\
\hline STLS1 & Employees in my organization feel good to be around their superiors \\
\hline STLS2 & $\begin{array}{l}\text { Superiors in my organization communicate in the simple word that is easy to } \\
\text { understand. }\end{array}$ \\
\hline STLS3 & In my organization, employees can think about old problems in new ways. \\
\hline STLS4 & My organization help employees to develop themselves. \\
\hline STLS5 & $\begin{array}{l}\text { Employees in my organization are told what to do if they want to be rewarded } \\
\text { for their work. }\end{array}$ \\
\hline STLS6 & My organization is satisfied when its employees meet an agreed standard. \\
\hline STLS7 & Employees in my organization have complete faith in their superiors. \\
\hline STLS8 & $\begin{array}{l}\text { Superiors in my organization have appealing images about what its employees } \\
\text { can do. }\end{array}$ \\
\hline
\end{tabular}

STLS9 Superiors in my organization provide workers with new ways of looking at puzzling things.

STLS10 Superiors in those organization communicate to their subordinates about their performance.

STLS11 Superiors in this organization provide rewards when employees reach their goals.

STLS12 As long as things are working, my superiors in this organization do not try to change anything.

STLS13 Employees in my organization are proud to be associated with the organization.

STLS14 My organization help employees find meaning in their work.

STLS15 My organization gets it, employees, to rethink ideas that they had never questioned before.

STLS16 In my organization, personal attention is given to those staffs that seem rejected. 
STLS17 In my organization, employees are told the standards they have to know to carry out their work.

STLS18 Superiors in my organization, have a clear understanding of where the organization is going.

STLS19 Superiors in my organization have a clear sense of where he/she want the organization to be in the next five years.

Table. 2. Scale of Competitive Advantage

\begin{tabular}{lll}
\hline Items & Statements & Sources \\
\hline CA1 & Our products are difficult for competitors to copy. & 2012) \\
CA2 & Our product designs are unique. \\
CA3 & $\begin{array}{l}\text { Our products do not have a significant advantage over those of our } \\
\text { competitors. }\end{array}$ \\
CA4 & Our ability to track changes in customer needs and wants is good. \\
CA5 & Our analysis of customer satisfaction with the competitors' products is good. \\
CA6 & Our surveillance of competitors is good. \\
CA7 & Our collection of strategic information about customers and competitors for \\
& use with strategic planning is good. \\
CA8 & The quickness of response to meeting changes in customer needs and wants? \\
CA9 & Response to customer complaints? \\
CA10 & Efforts to make product/service changes to overcome customer \\
CA11 & Sissatisfaction with existing products? \\
CA12 & Response to competitive moves in the market place?
\end{tabular}

Table. 3. Scale of Ambidexterity

\begin{tabular}{|c|c|c|}
\hline Items & Statements & Sources \\
\hline AMD1 & The structural differentiation & $\begin{array}{l}\text { Mohamad } \\
\text { Faizal, 2014) }\end{array}$ \\
\hline AMD2 & The units that are specialized in specific functions & \\
\hline AMD3 & The units that are focused on either short or long term objectives & \\
\hline AMD4 & $\begin{array}{l}\text { The line and staff departments that are structurally separated within the } \\
\text { organization }\end{array}$ & \\
\hline AMD5 & $\begin{array}{l}\text { The innovation and production activities that are structurally separated } \\
\text { within the organization }\end{array}$ & \\
\hline AMD6 & The customersee needs that are served from separate departments & \\
\hline AMD7 & Take initiative and alert to opportunities beyond the confines of your jobs & \\
\hline AMD8 & Seek out opportunities and cooperative to combines your efforts with others & \\
\hline AMD9 & Act as a broker who always looking to build internal linkages & \\
\hline AMD10 & Act as a multi-tasker who comfortable wearing more than one „hatee & \\
\hline AMD1 1 & The individual who refine and renew their knowledge, skills, and expertise & \\
\hline
\end{tabular}




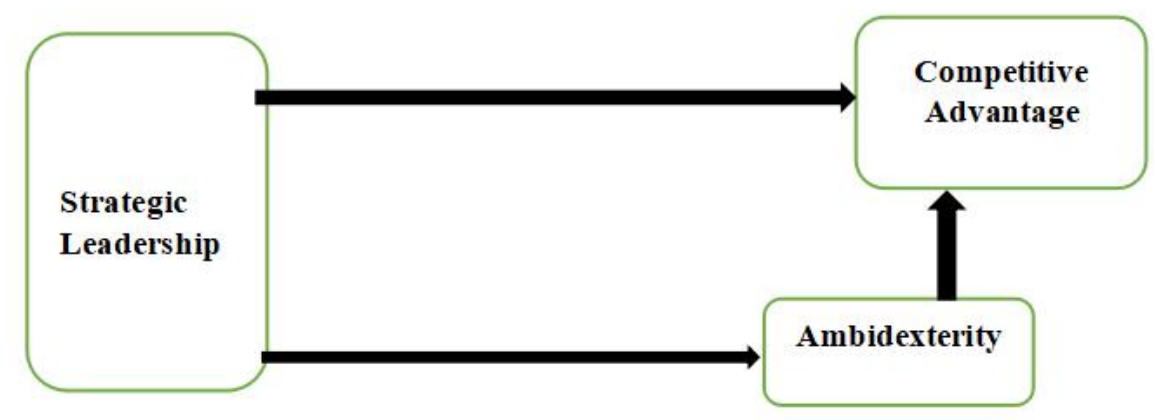

Fig. 1. Theoretical Framework

\section{Findings}

The findings exposed the convergent validity that shows the links among the items and figures highlighted that the high linkage between the items and valid convergent validity because the values of Alpha and CR are higher than 0.70 while the values of AVE and loading are more than 0.40 . These values are highlighted in Table 4.

Table. 4. Convergent Validity

\begin{tabular}{|c|c|c|c|c|}
\hline Constructs & Items & Loadings & CR & AVE \\
\hline \multirow[t]{16}{*}{ Strategic Leadership } & STLS19 & 0.986 & 0.945 & 0.532 \\
\hline & STLS18 & 0.642 & & \\
\hline & STLS17 & 0.706 & & \\
\hline & STLS16 & 0.696 & & \\
\hline & STLS15 & 0.989 & & \\
\hline & STLS14 & 0.802 & & \\
\hline & STLS13 & 0.478 & & \\
\hline & STLS12 & 0.815 & & \\
\hline & STLS10 & 0.445 & & \\
\hline & STLS8 & 0.444 & & \\
\hline & STLS7 & 0.641 & & \\
\hline & STLS6 & 0.707 & & \\
\hline & STLS5 & 0.701 & & \\
\hline & STLS4 & 0.982 & & \\
\hline & STLS3 & 0.805 & & \\
\hline & STLS2 & 0.464 & & \\
\hline \multirow[t]{10}{*}{ Competitive Advantage } & CA11 & 0.980 & 0.909 & 0.515 \\
\hline & CA10 & 0.568 & & \\
\hline & CA9 & 0.577 & & \\
\hline & CA8 & 0.985 & & \\
\hline & CA7 & 0.748 & & \\
\hline & CA6 & 0.702 & & \\
\hline & CA5 & 0.763 & & \\
\hline & CA4 & 0.576 & & \\
\hline & CA3 & 0.418 & & \\
\hline & $\mathrm{CA} 2$ & 0.651 & & \\
\hline Ambidexterity & AMD1 1 & 0.408 & 0.930 & 0.579 \\
\hline
\end{tabular}




$\begin{array}{ll}\text { AMD9 } & 0.521 \\ \text { AMD8 } & 0.741 \\ \text { AMD7 } & 0.822 \\ \text { AMD6 } & 0.841 \\ \text { AMD5 } & 0.858 \\ \text { AMD4 } & 0.792 \\ \text { AMD3 } & 0.834 \\ \text { AMD2 } & 0.842 \\ \text { AMD1 } & 0.808\end{array}$

The findings also exposed the discriminant validity that shows the links among the variables and figures highlighted that the that shows the link with current variables are more than the value that show the link with other variables. These values are highlighted in Table 5.

Table. 5. Discriminant Validity

\begin{tabular}{lccc}
\hline & STLS & CA & AMD \\
\hline STLS & 0.729 & & \\
CA & 0.125 & 0.718 & \\
AMD & 0.164 & 0.353 & 0.761 \\
\hline
\end{tabular}

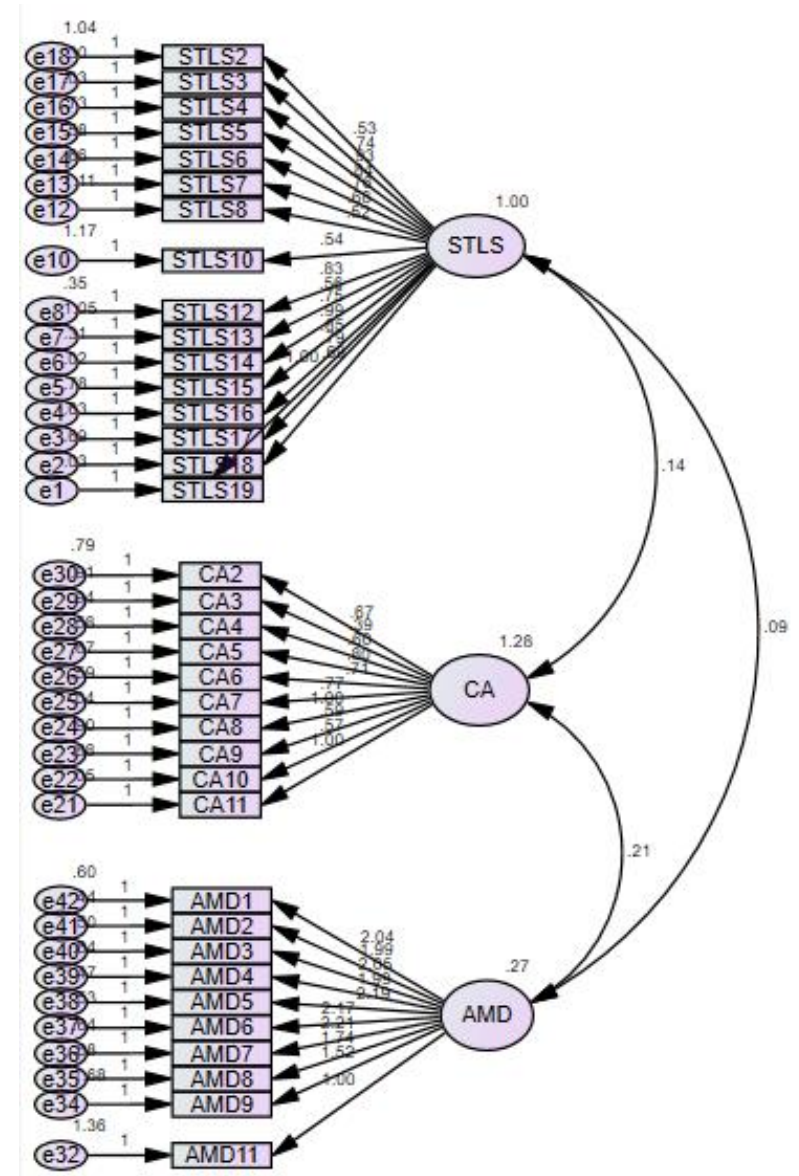

Fig. 2. Measurement Model Assessment

The results also indicated that positive linkage among the links of strategic leadership and competitive advantages and accept $\mathrm{H} 1$ because the beta has a positive sign while $\mathrm{t}$-values are larger than 1.64 and $\mathrm{p}$-values 
are less than 0.05 . However the strategic leadership has positive linkage with ambidexterity and ambidexterity has positively linked with a competitive advantage and accept $\mathrm{H} 2$ and $\mathrm{H} 3$ along with ambidexterity positively mediates among the links of strategic leadership and competitive advantage because the beta has positive sign while t-values are larger than 1.64 and p-values are less than 0.05 . These values are highlighted in Table 6, Table 7 and Figure 3.

Table. 6. Direct and Indirect Relationships

\begin{tabular}{|c|c|c|c|c|c|c|}
\hline \multicolumn{3}{|c|}{ Relationships } & \multirow{2}{*}{$\begin{array}{l}\text { Beta } \\
0.085\end{array}$} & \multirow{2}{*}{$\begin{array}{l}\text { S.D. } \\
0.033\end{array}$} & \multirow{2}{*}{$\begin{array}{c}\text { t-statistics } \\
2.569\end{array}$} & \multirow{2}{*}{$\begin{array}{c}\text { p-values } \\
0.010\end{array}$} \\
\hline AMD & $<---$ & STLS & & & & \\
\hline $\mathrm{CA}$ & $<---$ & STLS & 0.078 & 0.024 & 3.250 & 0.022 \\
\hline $\mathrm{CA}$ & $<---$ & AMD & 0.741 & 0.161 & 4.606 & $* * *$ \\
\hline
\end{tabular}

Table. 7. Mediating effects

\begin{tabular}{|l|c|c|c|}
\hline Relationships & Beta & Lower Limits & Upper Limits \\
\hline CA\&AMD $\leftarrow$ STLS & 0.056 & 0.019 & 0.108 \\
\hline
\end{tabular}

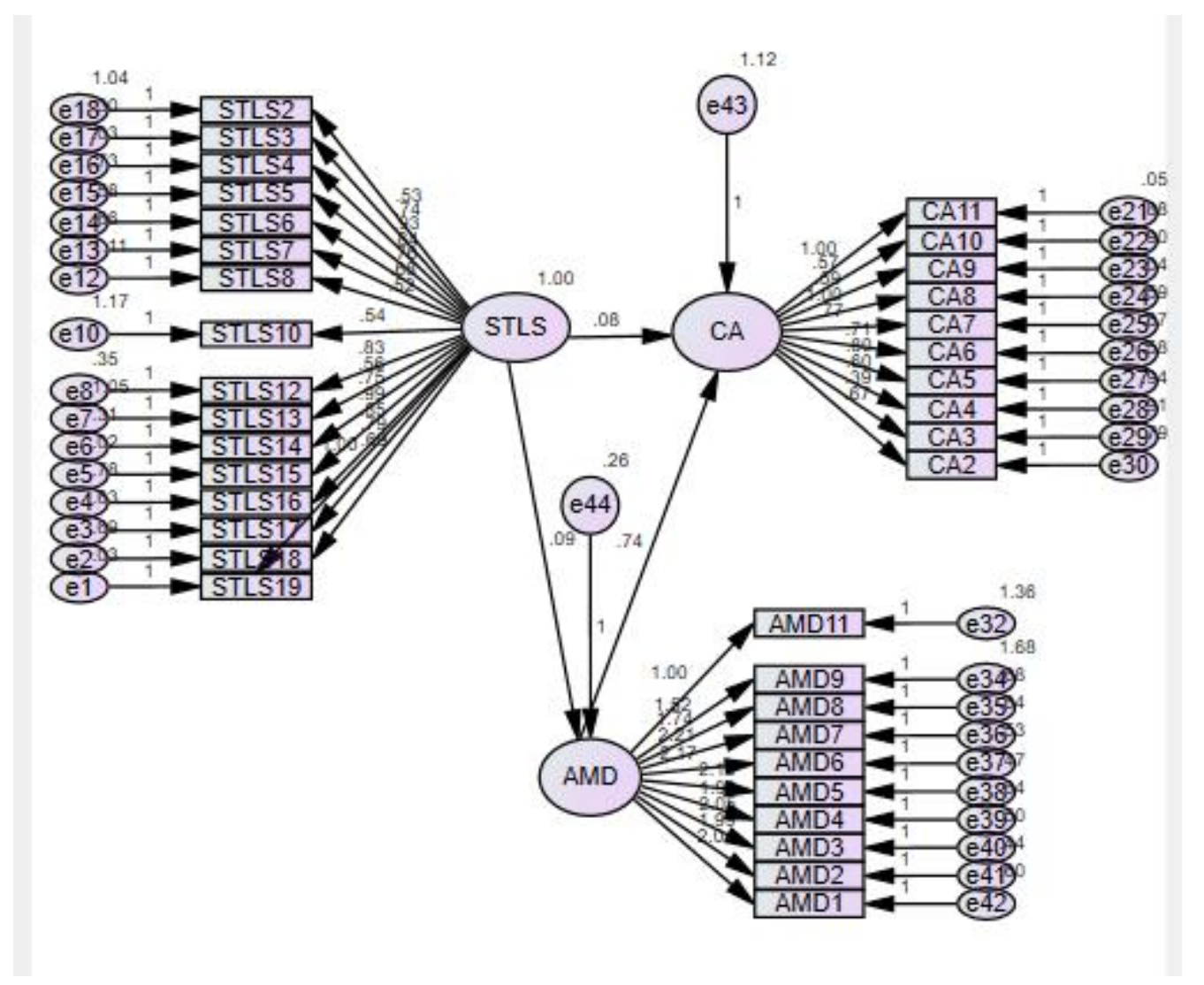

Fig. 3. Structural Model Assessment

\section{Discussion and Implications}

The results indicated that the positive nexus has been found among the links of strategic leadership and competitive advantage. These outcomes are similar to the outcomes of the [8] who also exposed that the positive linkage among the strategic leadership and competitive advantage. In addition, a study by [39] also exposed in their research that the competitive advantage of the companies depends on the strategic leadership 
of the organization. The findings also exposed that the ambidexterity positive mediates among the links of strategic leadership and competitive advantage of the Islamic banks in Jordan. These outcomes are also matched with the results of [6] who also examined that the strategic management along with ambidexterity positively influenced the competitive advantage. The strategic leadership style of the organization could improve the competitive advantage by applying the reasonable strategies in the business process of the organization. In addition, the leadership that are stronger in developing strategy related to the business process that could enhance the competitive advantage along with the performance of the organization [29] and this could be similar as the outcomes of the ongoing study. Moreover, ambidexterity characteristics of the organization could also move then towards the competitive advantage because this ability could force the organization towards efficient management that enhance the performance of the organization and similar to the current study findings.

These findings provided the guidelines to the regulators while formulating regulation for competitive advantage along with leadership and also helpful for the future studies who aim to investigate this area in the future. This study also suitable for the policy implementation authorities that they should implement the policies that enhance the strategic leadership in the organization along with the ambidexterity characteristics that improve the firm performance. This study has contributed to the literature related to the strategic leadership and its impact on the competitive advantage along with the ambidexterity and its mediating role among the links of strategic leadership and competitive advantage. This study also contributed to the literature of competitive advantage in the context of Islamic banks. This study has implication in the Islamic banks of Jordan and other countries that how strategic leadership improve the competitive advantage along with the performance of the organization.

\section{Conclusion and Limitations}

The present study has concluded that the Islamic banks in Jordan have effective strategic leadership along with the high organizational ambidexterity that improves the competitive advantage of the banks. The ambidexterity characteristic of the Islamic banks in Jordan has played an essential role to improve the leadership positive influence on the competitive advantage and performance of the institution. This study guided to the management of the banks that they should focus on their strategic leadership that must enhance the competitive advantages of the banks. This study has some limitations such as it takes only one predictor and suggested that future studies should add more predictors in their study. In addition, the current study has investigated only the Islamic banks and recommended that future studies should include conventional banks also. Finally, the present study ignores the moderating role in the model and suggested that future study should also incorporate this point in their analysis.

\section{References}

[1] Abazeed, R. (2020). Impact of strategic capabilities on organizational ambidexterity in the commercial banks in Jordan: The mediating role of knowledge management. Management Science Letters, 10(7), 1445-1456.

[2] Al-Atwi, A. A., Amankwah-Amoah, J., \& Khan, Z. (2019). Micro-foundations of organizational design and sustainability: The mediating role of learning ambidexterity. International Business Review, 10, 1-11. doi: https://doi.org/10.1016/j.ibusrev.2019.101656

[3] Al-Khasawneh, R. O. H. (2020). Cost-Driving Strategy Under the Use of E-Business to Achieve a Competitive Advantage in a Digital Economy Environment. International Journal of Economics and Finance, 12(1), 1-70.

[4] Alatailat, M., Elrehail, H., \& Emeagwali Okechukwu, L. (2019). High performance work practices, organizational performance and strategic thinking: A moderation perspective. International Journal of Organizational Analysis, 27(3), 370-395. doi: 10.1108/IJOA-10-2017-1260

[5] Ali, Z., \& Mehreen, A. (2019). Understanding succession planning as a combating strategy for turnover intentions. Journal of Advances in Management Research, 16(2), 216-233. doi: 10.1108/JAMR-09-2018-0076 
[6] Asif, M. (2020). Strategic leadership and ambidextrous learning. International Journal of Quality and Service Sciences, 12(1), 1-14.

[7] Augustine, Y. (2019). The Adoption of Environmental Consciousness and Environmental Leadership as driver of Competitive Advantage. OIDA International Journal of Sustainable Development, 12(09), 25-34.

[8] Banmore, O., Adebayo, L., Mudashiru, M., Oluwatooyin, G., Falilat, A., \& Olufunke, O. (2019). Effect of strategic leadership on competitive advantage of selected quoted insurance companies in Nigeria. The Journal of Accounting and Management, 9(2), 70-78.

[9] Birru, W. T., Runhaar, P., Zaalberg, R., Lans, T., \& Mulder, M. (2019). Explaining Organizational Export Performance by Single and Combined International Business Competencies. Journal of Small Business Management, 57(3), 1172-1192. doi: 10.1111/jsbm.12403

[10] Brotspies, H., \& Weinstein, A. (2019). Rethinking business segmentation: a conceptual model and strategic insights. Journal of Strategic Marketing, 27(2), 164-176. doi: 10.1080/0965254X.2017.1384750

[11] Brunton, M., Kankaanranta, A., Louhiala-Salminen, L., \& Jeffrey, L. (2015). Are Strategic Communication Management Competencies and Personal Attributes Global? A Case Study of Practice in Finland and New Zealand. International Journal of Business Communication, 56(2), 151-172. doi: 10.1177/2329488415608846

[12] Chen, R., Lee, Y.-D., \& Wang, C.-H. (2020). Total quality management and sustainable competitive advantage: serial mediation of transformational leadership and executive ability. Total Quality Management \& Business Excellence, 31(5-6), 451-468. doi: 10.1080/14783363.2018.1476132

[13] de Vasconcellos, S. L., Garrido, I. L., \& Parente, R. C. (2019). Organizational creativity as a crucial resource for building international business competence. International Business Review, 28(3), 438-449. doi: https://doi.org/10.1016/j.ibusrev.2018.11.003

[14] Dhir, S., \& Dhir, S. (2020). Modeling of strategic thinking enablers: a modified total interpretive structural modeling (TISM) and MICMAC approach. International Journal of System Assurance Engineering and Management, 11(1), 175-188. doi: 10.1007/s13198-019-00937-z

[15] Diesel, R., \& Scheepers Caren, B. (2019). Innovation climate mediating complexity leadership and ambidexterity. Personnel Review, 48(7), 1782-1808. doi: 10.1108/PR-11-2018-0445

[16] El Namaki, M. (2020). Could Business Organizations Simulate the Brain's Implicit Learning Process? And Apply That to Strategic Thinking? International Journal of Management and Applied Research, 7(1), 72-80.

[17] Eldor, L. (2020). How Collective Engagement Creates Competitive Advantage for Organizations: A BusinessLevel Model of Shared Vision, Competitive Intensity, and Service Performance. Journal of Management Studies, 57(2), 177-209. doi: 10.1111/joms.12438

[18] Fainshmidt, S., Wenger, L., Pezeshkan, A., \& Mallon, M. R. (2019). When do Dynamic Capabilities Lead to Competitive Advantage? The Importance of Strategic Fit. Journal of Management Studies, 56(4), 758-787. doi: $10.1111 /$ joms. 12415

[19] Ford Lumban, G., Suci, R., \& Tokuro, M. (2020). The Development of Information System with Strategic Planning for Integrated System in the Indonesian Pharmaceutical Company. Open Engineering, 10(1), 721-732. doi: https://doi.org/10.1515/eng-2020-0081

[20] George, B., Walker, R. M., \& Monster, J. (2019). Does Strategic Planning Improve Organizational Performance? A Meta-Analysis. Public Administration Review, 79(6), 810-819. doi: 10.1111/puar.13104

[21] Hamadamin, H. H., \& Atan, T. (2019). The Impact of Strategic Human Resource Management Practices on Competitive Advantage Sustainability: The Mediation of Human Capital Development and Employee Commitment. Sustainability, 11(20), 5782-5789. doi: 10.3390/su11205782

[22] Hauser, A., Eggers, F., \& Güldenberg, S. (2020). Strategic decision-making in SMEs: effectuation, causation, and the absence of strategy. Small Business Economics, 54(3), 775-790. doi: 10.1007/s11187-019-00152-x

[23] Idahosa, G. E.-o., \& Vincent, L. (2019). Strategic competence and agency: individuals overcoming barriers to change in South African higher education. Third World Quarterly, 40(1), 147-162. doi: 10.1080/01436597.2018.1535273 
[24] Jafarinia, S., Nour Ali, M. R., \& Razmavar, T. (2019). The effects of entrepreneurial orientation and Dynamic Capabilities on firm performance with mediating role of innovation ambidexterity. Innovation Management in Defense Organizations, 2(3), 119-142.

[25] Klimova, I. I., Klimova, G., \& Dubinka, S. (2019). Students' communicative competence in the context of intercultural business communication. XLinguae, 12(1), 207-218.

[26] Kowo, S. A., \& Akinbola, O. A. (2019). Strategic leadership and sustainability performance of small and medium enterprises. Ekonomicko-manazerske spektrum, 13(1), 38-50.

[27] Larigol, Z., Ghanifar, M.-h., Aho, G., Shahabizadeh, F., \& Jarahi, J. (2020). Role of Spiritual Intelligence in Entrepreneurial Self-efficacy With Mediatin of Strategic Thinking. ميانجى با كار آفرينانه خودكار آمدى در معنوى هوش نقش] ر اهبردى تفكر كرى]. muq-hsme, 7(2), 50-58.

[28] Malik, A. (2019). Creating competitive advantage through source basic capital strategic humanity in the industrial age 4.0. International Research Journal of Advanced Engineering and Science, 4(1), 209-215.

[29] Mohamad Faizal, A. Z. (2014). Organisational learning, organisational ambidexterity, environmental turbulence, and NPD performance of Malaysian's manufacturing sector. Universiti Utara Malaysia.

[30] Mom, T. J., Chang, Y.-Y., Cholakova, M., \& Jansen, J. J. (2019). A multilevel integrated framework of firm HR practices, individual ambidexterity, and organizational ambidexterity. Journal of Management, 45(7), 3009-3034.

[31] Muñoz, P., \& Kimmitt, J. (2019). Social mission as competitive advantage: A configurational analysis of the strategic conditions of social entrepreneurship. Journal of Business Research, 101, 854-861. doi: https://doi.org/10.1016/j.jbusres.2018.11.044

[32] Nikitina, T., \& Lapiņa, I. (2019). Creating and managing knowledge towards managerial competence development in contemporary business environment. Knowledge Management Research \& Practice, 17(1), 96-107. doi: $10.1080 / 14778238.2019 .1569487$

[33] Norshafizah, H. (2012). Business performance of women-owned SMEs in Malaysia: Learning and entrepreneurial orientations and the mediating roles of competitive advantage. Universiti Utara Malaysia.

[34] Palladan, A. A. (2017). Effects of strategic leadership, organizational innovativeness, information technology capability on effective strategy implementation. Universiti Utara Malaysia.

[35] Papadas, K.-K., Avlonitis, G. J., Carrigan, M., \& Piha, L. (2019). The interplay of strategic and internal green marketing orientation on competitive advantage. Journal of Business Research, 104, 632-643. doi: https://doi.org/10.1016/j.jbusres.2018.07.009

[36] Peters, M. D., Gudergan, S., \& Booth, P. (2019). Interactive profit-planning systems and market turbulence: A dynamic capabilities perspective. Long Range Planning, 52(3), 386-405. doi: https://doi.org/10.1016/j.lrp.2018.03.004

[37] Qammar, R., \& Abidin, R. Z. U. (2020). Mediating and Moderating Role of Organizational Ambidexterity and Innovative Climate among Leadership Styles and Employee Performance. Journal of Management Info, 7(1), 1-9.

[38] Shaik Aqueeb, S., \& Dhir, S. (2020). A meta-analytical review of factors affecting the strategic thinking of an organization. foresight, 22(2), 144-177. doi: 10.1108/FS-08-2019-0076

[39] Shao, Z. (2019). Interaction effect of strategic leadership behaviors and organizational culture on IS-Business strategic alignment and Enterprise Systems assimilation. International Journal of Information Management, 44, 96108.

[40] Sukhari, A., \& de Villiers, C. (2019). The Influence of Integrated Reporting on Business Model and Strategy Disclosures. Australian Accounting Review, 29(4), 708-725. doi: 10.1111/auar.12264

[41] Szymanski, M., Fitzsimmons, S. R., \& Danis, W. M. (2019). Multicultural managers and competitive advantage: Evidence from elite football teams. International Business Review, 28(2), 305-315. doi: https://doi.org/10.1016/j.ibusrev.2018.10.003

[42] van Assen, M. F. (2020). Empowering leadership and contextual ambidexterity - The mediating role of committed leadership for continuous improvement. European Management Journal, 38(3), 435-449. doi: https://doi.org/10.1016/j.emj.2019.12.002 
A. Sibghatullah \& M. Raza/ IJIIS Vo1. 3 No. 2, September 2020, pp. 67-80

[43] Venugopal, A., Krishnan, T. N., Kumar, M., \& Upadhyayula, R. S. (2019). Strengthening organizational ambidexterity with top management team mechanisms and processes. The International Journal of Human Resource Management, 30(4), 586-617. doi: 10.1080/09585192.2016.1277369

[44] Yamin, M. (2020). Examining the role of transformational leadership and entrepreneurial orientation on employee retention with moderating role of competitive advantage. Management Science Letters, 10(2), 313-326.

[45] Yang, H., \& Yang, J. (2019). The effects of transformational leadership, competitive intensity and technological innovation on performance. Technology Analysis \& Strategic Management, 31(3), 292-305. doi: $10.1080 / 09537325.2018 .1498475$

[46] Yap, C. S., Ahmad, R., Jalaludin, F. W., \& Hashim, N. A. (2020). Managerial Ambidexterity and Firm Performance: The Mediating Role of Knowledge Brokerage. International Journal of Knowledge Management (IJKM), 16(3), 52-69. 